\title{
Evaluation of low intensity laser's action on silicone mammary implant pseudocapsules in rats $^{1}$
}

\author{
Avaliação do laser de baixa intensidade sobre a pseudocápsula de implantes mamários de \\ silicone em ratos
}

\author{
Aristides Palhares ${ }^{\mathrm{I}}$, Silvana Artioli Schellini" ${ }^{\mathrm{II}}$, Claudia Helena Pellizzon ${ }^{\mathrm{III}}$, Carlos Roberto Padovani ${ }^{\mathrm{IV}}$, Patrícia Dorsa ${ }^{\mathrm{V}}$ \\ ${ }^{I} \mathrm{PhD}$, Assistant Professor, Department of Surgery and Orthopedic, Botucatu Faculty of Medicine, UNESP, Brazil. \\ ${ }^{\text {II }}$ Full Professor, Department of Ophthalmology, Otorhinolaryngology and Head and Neck Surgery, Botucatu Faculty of Medicine, UNESP, Brazil. \\ III $\mathrm{PhD}$, Assistant Professor, Botucatu Biosciences Institute, UNESP, Brazil. \\ IV Full Professor, Botucatu Biosciences Institute, UNESP, Brazil. \\ ${ }^{v}$ MD. Resident, Department of Surgery and Orthopedic, Botucatu Faculty of Medicine, Brazil.
}

\begin{abstract}
Purpose: To evaluate the effect of low intensity laser on the pseudocapsula contraction that occurs around silicone implants. Methods: 60 male rats divided in two experimental groups received a silicone implant in the subcutaneous of the dorsal region. Group I: animals received implants in the subcutaneous dorsal region and did not receive any treatment; Group II: animals received seven irradiation sessions with low intensity laser after they had received subcutaneous implants. Thirty, 60 and 180 days after the surgery, tonometric evaluation of the implants was conducted. After that, the animals were sacrificed, study material was removed and prepared for histological examination. The thickness of the pseudocapsule and the inflammatory reaction were morphometrically quantified. Data obtained were statistically analyzed using the Variance method, and Tukey's Test $(\mathrm{P}<0.0$ 5). Results: Group II animals had significant lower pressure. The histological study did not show a significant difference between the groups, but only a higher number of swollen vessels in Group II. The thickness of pseudocapsule around Group II's implants lower than in Group I. Conclusion: The low intensity laser modify tissue's reparation process around the implants suggesting it may be useful to model contractures that are formed around silicone implants.
\end{abstract}

Key words: Breast Implants. Laser Therapy, Low-Level. Silicones. Rats.

\section{RESUMO}

Objetivo: Avaliar o efeito do laser de baixa intensidade sobre a contração da pseudocápsula que ocorre ao redor de implantes de silicone. Métodos: 60 ratos machos divididos em dois grupos receberam implante de silicone. Grupo I: implante no subcutâneo da região dorsal, sem tratamento após a cirurgia; Grupo II: animais receberam sete sessões de irradiação com laser de baixa intensidade após o implante. Trinta, 60 e 180 dias após a cirurgia, foi feita a tonometria dos implantes, Em seguida, os animais foram sacrificados, removendo-se o material de estudo que foi preparado para exame histológico, avaliando-se morfometricamente a espessura da pseudocápsula e a reação inflamatória. A análise estatistica pela técnica da Análise de Variância e Teste de Tukey $(\mathrm{P}<0.05)$. Resultados: Pressões significativamente menores foram encontradas nos animais do grupo Grupo II. O estudo histológico não mostrou diferença significativa entre os grupos, destacando-se apenas maior quantidade de vasos intumescidos no Grupo II. A espessura da pseudocápsula foi menor no Grupo II. Conclusão: O laser de baixa intensidade altera o processo de reparação tecidual ao redor dos implantes, sugerindo que o mesmo possa ser útil para a modelação das contraturas que se estabelecem ao redor dos implantes de silicone.

Descritores: Implantes de Mama. Terapia a Laser de Baixa Intensidade. Silicones. Rats.

${ }^{1}$ Research performed at the Botucatu Medicine Faculty, State University of Sao Paulo (UNESP), Brazil.

\section{Introduction}

Despite their wide acceptance, silicone breast implants entail problems like fibrous encapsulation and when tissue is contracted, the breast hardens and the implant can fold. Some modifications have been made that aim at reducing the contraction of such capsules but a definitive solution to the problem is yet to emerge. ${ }^{1}$ 
Capsules, or to put it better, pseudocapsules, occur in a normal process of tissue reparation: conjunctive tissue tries to isolate the foreign body that is being introduced into the organism. The processes that lead to capsular contractions are of variable and non-uniform intensity and their etiology has not yet been established and there are two major hypotheses: the contraction afford appear due to proliferation of myofibroblasts, or would be triggered by an infectious stimulus. ${ }^{2}$

A number of methods drawing on the two theories have been tried to control the process of pseudocapsule formation, e.g., application of antibiotics, ${ }^{3}$ corticosteroids ${ }^{4}$ and even physical methods like modification of the surface structure of implants; employment of pulsed electromagnetic energy ${ }^{5}$ and of ultrasound. ${ }^{6}$

Low intensity laser (therapeutic laser) has already been used in odontology as a modulator of the inflammation process to reduce tooth sensitivity to cold and sweet foods and to alleviate post-surgical pain and inflammation. ${ }^{7,8}$

Low intensity laser's wavelength is found in both the visible and the invisible portion of the electromagnetic spectrum. The mechanism of its functioning is not completely understood, but it is assumed that photoreceptive structures inside cells are activated and stimulate or inhibit enzymatic activities and photochemical reactions. ${ }^{8}$ With a complex form and a response depending on the state of cell activation, the process of photo-activation has three symptoms: it impacts directly on the cell (primary or immediate effect) and enhances the cellular metabolism, it accelerates the blood flow and the lymphatic drainage; it has a delayed or systematic effect that manifests itself as an activation of the immunological system. ${ }^{9}$
These effects have been observed both in vitro and in vivo, resulting in some clinical uses of low intensity laser, e.g., alleviation of pain and stimulation of tissue reparation; reduction of edema and hyperemia in inflammatory process; prevention of infection; improving recuperation after paresthesia and paralysis. ${ }^{9}$

All benefits of low intensity lasers notwithstanding, its contribution to control pseudocapsule formation that occurs in the vicinity of silicone breast implants is not known so far.

Therefore, the purpose of the present study, which employs an experimental method, is to assess the effects of low intensity laser irradiation on pseudocapsule that appeared in the vicinity of silicone breast implants.

\section{Methods}

An experimental study that involved 60 male Wistar rats (Rattus norvegicus) weighing between 160 and 180 grams was conducted at the Faculty of Medicine of Botucatu-UNESP, São Paulo. The use of laboratory animals followed the Council for International Organization of Medical Sciences ethical code for animals experimentation and the Brazilian College on Animal Experimentation.

Silicone gel implants with a smooth surface and thickness of two millimeters were planted in the rats' subcutaneous part of the dorsal region under general anesthesia and under aseptic and antiseptic conditions (Figure 1).

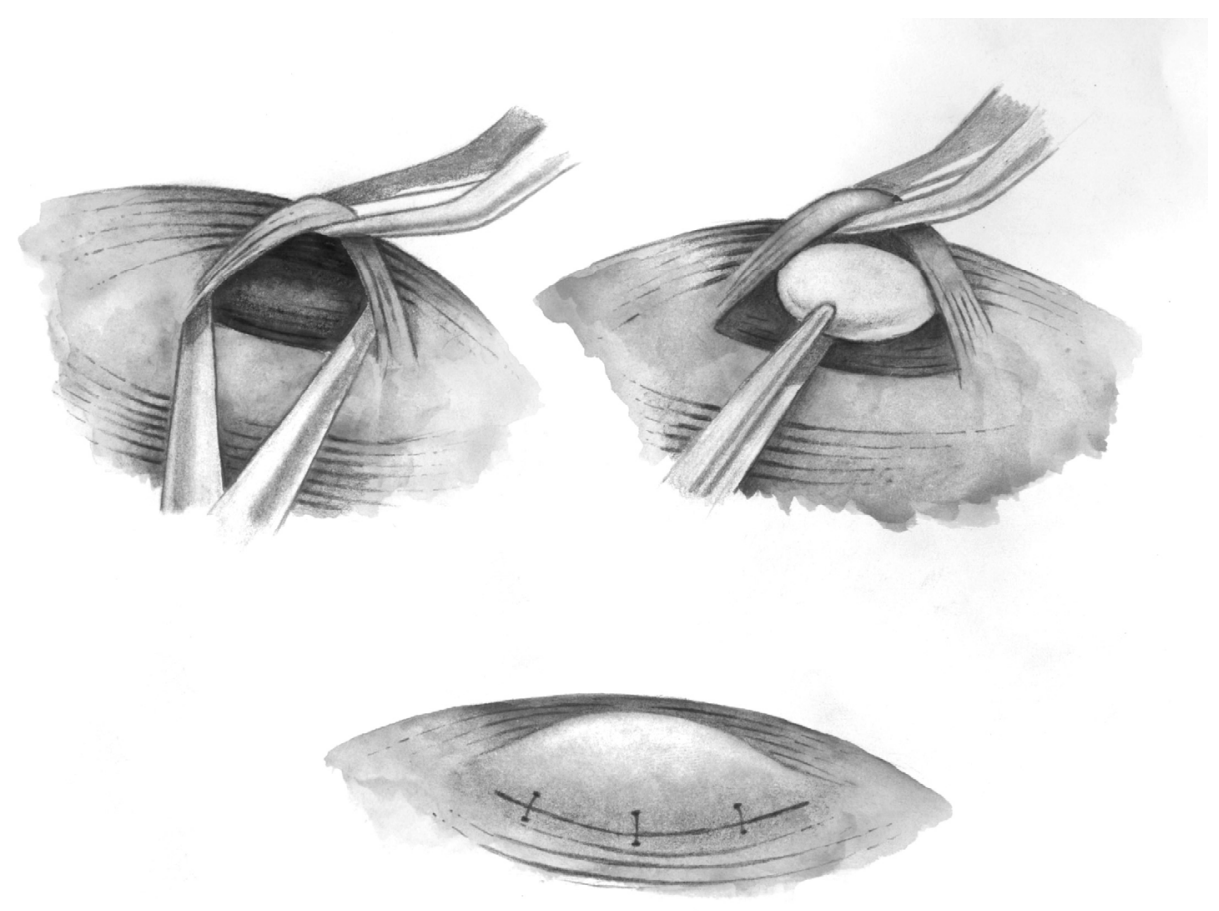

FIGURE 1 - Scheme displaying the insertion of implants in the dorsal region of rats 

groups:

The animals were randomly divided into two experimental

1) Group I - animals that received a silicone implant and did not receive a treatment after surgery;

2) Group II - animals that received a silicone implant and were irradiated using low intensity laser,,applied in four places over the implant. The first treatment took place immediately after the surgery and the total number of sessions was seven, every second day during a period of 14 days. The energy applied was $1 \mathrm{~J} / \mathrm{cm}^{2}$ per pulse. The laser used was the GaAIAs (gallium aluminum arsenide) semiconductor low intensity laser, namely the Twin model (MM Optics, Brazil) with wavelength of $780 \mathrm{~nm}$ in the continuous mode.

To evaluate the pressure of the pseudocapsule on the implants, we conducted applanation tonometry 30, 90 and 180 days after the surgery using a digital applanation tonometer, model Tono-pen XL (Medtronic Inc, USA).

After tonometry, the animals were sacrificed using an overdose of pentobarbital sodium. The implants and adjacent tissue were removed and immediately fixed in $10 \%$ tamponed formol. Afterwards, the implant was removed from the pseudocapsule through an incision in its major diameter. The pseudocapsules were prepared for histological examinations and were dehydrated in a increasing series of alcohols, immersed in paraffin and graded slides were mounted so that each cut ran through the whole perimeter of the pseudocapsule. The slides were colored with hematoxylin and eosin (HE) and pseudocapsule cellularity and collagen fibers were evaluated by morphometric exam using a semi-automatic image analyzer Leica Qwin - Leica DMLN microscope (German) with processing program, measuring the thickness in six previously determined points and always in the same position in all the animals.

The data obtained in the tonometric exam were statistically evaluated using the non-parametric variance analysis for two-factor models. Morphometric data were analyzed using variance analysis for two-factor models along with Tukey's multiple comparison test at 0.05 significance level.

\section{Results}

Animals did not show behavioral alternations after the procedure and there were no infections in the surgical incisions during the experimental period. Two animals from Group II, died for unclear and not related to the treatment reason around the observation period lasted 180 days.

\section{Applanation tonometry of the implants}

In some evaluations, the minimum value that the tonometer can distinguish (4 $\mathrm{mmHg}$ ) was not achieved. Consequently, those evaluations were assigned a value of $5 \mathrm{mmHg}$, which is the bottom limit of the device's reliability. A statistical analysis of tonometric measurements did not show any difference between the groups on the $30^{\text {th }}$ and on the $90^{\text {th }}$ day. However, the tonometric values of Group I were higher on $180^{\text {th }}$ day, with a statistically significant difference. In other words, higher pressure was observed in implants in Group I, in comparison with Group II, 180 days after they were include (Table 1).

Comparing the development of tonometric values within groups, the values of animals belong to Group I had an upward trend: statistically significant difference appeared between 30 and 90 as well as between 90 and 180 days. In other words, the pressure in implants gradually increased during the experimental period. As far as Group II is concerned, the increase was lower and a significant difference was found only between 30 and 90 days. After that, the values did not change significantly until the end of the experiment (Table 1).

TABLE1 - Median values (minimum value, maximum value) for variable applanation tonometry conducted under the implants (measured in $\mathrm{mmHg}$ ) according to group and moment of evaluation along with results of statistical analysis

\begin{tabular}{|c|c|c|c|c|}
\hline \multirow[b]{2}{*}{ Group } & \multicolumn{3}{|c|}{ Moment of sacrifice } & \multirow{2}{*}{$\begin{array}{c}\text { Result of } \\
\text { statistical } \\
\text { test } \\
\text { (P-value) }\end{array}$} \\
\hline & 30 days & 90 days & 180 days & \\
\hline GI & $5(<5 ; 8)$ a A & $7(5 ; 16)$ a B & $14,5(6 ; 18) b \mathrm{C}$ & $P<0.001$ \\
\hline GII & $<5(<5 ; 5)$ a $A$ & $7,5(<5 ; 14)$ a B & $7(<5 ; 14)$ a B & $P<0.005$ \\
\hline $\begin{array}{c}\text { Result of } \\
\text { statistical test } \\
\text { (P-value) }\end{array}$ & $P>0.05$ & $P>0.05$ & $P<0.05$ & \\
\hline
\end{tabular}

Lower-case letters in red: comparison between groups for a given moment of sacrifice $(P<0,05)$

Upper-case letters in green: comparison between moments of sacrifice within groups $(P<0,05)$

For given moments of observation: 30 days: $\mathrm{GI}=\mathrm{GII} ; 90$ days: $\mathrm{GI}=\mathrm{GII} 180$ days: $\mathrm{GI}>\mathrm{GII}$

For a given group: $\mathrm{Gl}$ : M30 < M90 < M180; GII: M30 < M90; M90 = M180; M30 < M180 


\section{Histological exam results}

Group I: After 30 days, the implants were surrounded by young fibroblasts with large nuclei, numerous small blood vessels and mild inflammatory infiltrate, basically caused by lymphocytes located around the implants. After 90 days, fibroblasts were more mature and dense. After 180 days, the fibroblasts were even more mature, with small nuclei and dense collagen fibers. The inflammatory infiltrate was not significant in every observed moment.

Group II: The response of the tissue observed in Group I also occurred in Group II but with a higher number of swollen blood vessels replete with red blood cells. Also In this group, there was no significant inflammatory infiltrate.

In other words, the histological evaluation demonstrated that the pseudocapsule that appears in the vicinity of implants had a similar pattern of cellularity and in the distribution of collagen fibers in both groups. The only difference between the two groups was enlarged blood vessels in Group II (Figure 2).
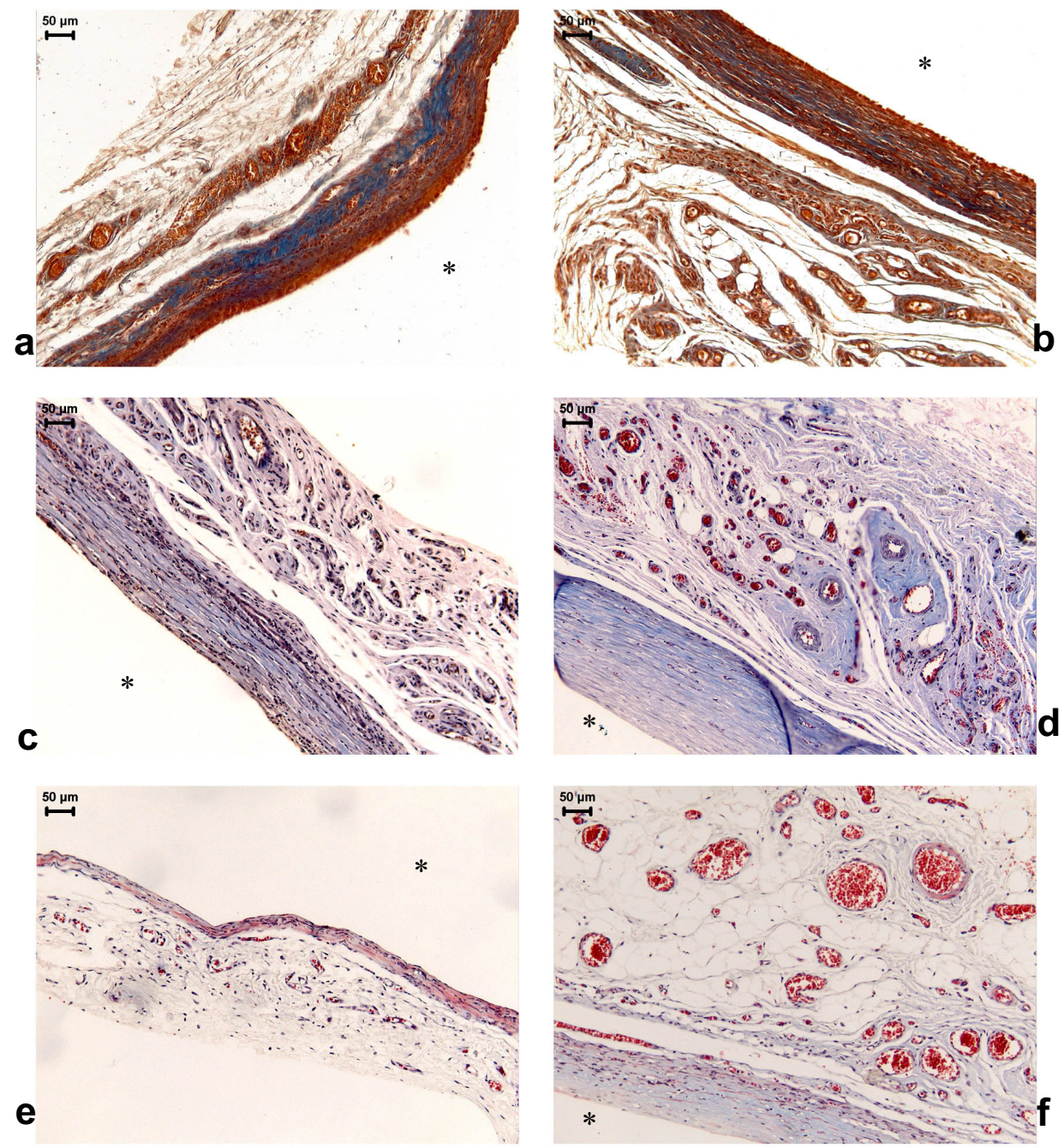

FIGURE 2 - Each group and in each moment of the project. No significant difference was observed in collagen fibers' cellularity and spatial distribution. The asterisk $(*)$ shows the place where the implant was inserted. Figures (a), (c), (e) are representative samples of Group I after 30, 90 and 180 days, respectively, and figures (b), (d), (f) are representative samples of group II after 30, 90 and 180 days, respectively. Note the high number of congested vessels in Group II

\section{Morphometric evaluation of pseudocapsule thickness}

Group I: Pseudocapsule thickness was larger in animals sacrificed on the $30^{\text {th }}$ day, decreasing on 90 days and with no significant difference between 90 and 180 days (Table 2).

Group II: No difference in pseudocapsule thickness occurred after 30 and 90 days neither at 90 and 180 days. Only comparing the pseudocapsule thickness after 30 days with after 180 days did a significant difference was observed.

Comparing the two groups, after 30 days the Group I animals had higher pseudocapsule thickness than Group II. The two groups had similar performance after 90 days. After 180 days, however, Group I again had higher values than Group II.
In other words, the pseudocapsules formed around the implants were thicker at the beginning of the experiment and reduced towards its end.

Another important observation arose out comparing both groups, when the Group II animals (treated with laser) had thinner pseudocapsules than the Group I rats. 
TABLE 2 - Average and standard deviation according to group and moment of sacrifice of values (mm) referring to thickness of the capsule that is formed around the implant

\begin{tabular}{|c|c|c|c|c|}
\hline \multirow{2}{*}{ Group } & \multicolumn{3}{|c|}{ Moment of sacrifice } & \multirow{2}{*}{$\begin{array}{c}\text { Result of } \\
\text { statistical } \\
\text { test (P- } \\
\text { value) }\end{array}$} \\
\hline & 30 days & 90 days & 180 days & \\
\hline G I & $105.02 \pm 29.88$ b B & $67.07 \pm 17.88$ а $A$ & $71.98 \pm 24.06$ b A & $P<0.01$ \\
\hline G II & $77.90 \pm 17.05$ а B & $66.40 \pm 18.88$ a $A B$ & $44.3 \pm 10.85$ a $A$ & $P<0.05$ \\
\hline $\begin{array}{l}\text { Result of } \\
\text { statistical } \\
\text { test (P- } \\
\text { value) }\end{array}$ & $P<0.01$ & $P>0.05$ & $P<0.01$ & \\
\hline
\end{tabular}

Lower-case letters in red: comparison between groups for a given moment of sacrifice $(P<0,05)$

Upper-case letters in green: comparison between moments of sacrifice within groups $(P<0,05)$

For given moments of observation: 30 days: $\mathrm{GI}>\mathrm{GIl} ; 90$ days: $\mathrm{Gl}=\mathrm{GIl} ; 80$ days: $\mathrm{Gl}>\mathrm{GII}$

For a given group: $\mathrm{GI}:(\mathrm{M} 30)>(\mathrm{M} 90=\mathrm{M} 180) ; \mathrm{GII}: \mathrm{M} 30=\mathrm{M} 90 ; \mathrm{M} 90=\mathrm{M} 180$, but $\mathrm{M} 30>\mathrm{M} 180$

\section{Discussion}

The pressure inside the implant is an important method to estimate the degree of capsular contraction ${ }^{9}$ and the applanation tonometry, routinely used to evaluate intraocular pressure, was an easy and usefull method for this. Another frequently employed method to determine the pressure that capsules exert on implants was proposed by Moore. ${ }^{10}$ Nevertheless, the latter method would not be easily applicable in our experimental model because the small-sized implants.

In pilot studies, another three ophthalmic tonometers were tested pointed out Tono-Pen XL was the easiest and with lowest error probability. In some evaluations, the results obtained were close to the reliability limit of the device $(4 \mathrm{mmHg})$ and to homogenize the values obtained, the results were approximated to the value of $5 \mathrm{mmHg}$ in both experimental groups.

The statistical analysis of tonometric values displayed significant differences between the groups after 180 days. On the other hand, when we assessed the differences within each group, we found that in Group I, there was a significant difference after 30, 90 and 180 days; in Group II no difference was detected between 90 and 180 days. These results show that the differences between groups become more perceptible over time probably because the pressure increases when the cicatricial process sets or a gradually contracts fibrous cover layer is formed around the implant.

It must be emphasized that in both groups the tonometric values tended to grow over time, which is in keeping with the hypothesis that pseudocapsular contraction is caused by cicatricial contraction of the wound in the process of tissue reparation. However, in Group II, tonometric values after 180 days were statistically lower than values of Group I, which suggested that according to the tonometric evaluation, laser irradiation seems to have succeeded in reducing the pressure exerted on the implant.
The introduction into the organism of any foreign substance with dimensions that do not allow phagocytosis induces pseudocapsule formation, consisting of collagen fibers parallel to the implant and this has been observed around of all implants inserted in the subcutaneous part of the experimental rats. The pseudocapsule is supposed to be thicker the stronger the inflammatory tissue reaction against to the implanted substance is. ${ }^{11}$ Thickness tends to decrease over time, as observed in the present study, once the process of cell count decline sets in and only fibroblasts and collagen remain in its composition. There is also a contraction related to the action of myofibroblasts. ${ }^{11}$

The capsular contraction itself is a part of the standard process of tissue reparation. There are various therapeutic methods to control the intensity of contraction. In the present study, we used a low intensity laser to this end.

The histologic pattern observed in the two groups was homogeneous throughout the experimental period and no significant inflammatory reaction appeared in either group probably because the implant was inserted under the rat's meaty pad, which, despite being muscular tissue, consists of a loose connective tissue, which may have caused a less intense inflammatory reaction. The homogeneity between groups suggests that the use of laser does not change the inflammatory reaction of the tissue when implants are inserted in the subcutaneous part of the dorsal region of rats. However, a higher number of enlarged and swollen vessels were observed in animals of Group II.

Morphometric analysis showed that the average thickness of the pseudocapsules shaped around the implants tended to decrease over time in both groups, nevertheless the Group I values were higher than those observed in Group II. 
Analyzing the Group I pseudocapsule thickness, highest average values were observed in animals sacrificed after 30 days and stable results occurred in animals sacrificed after 90 and 180 days. No significant difference was observed in the pseudocapsule average thickness comparing animals sacrificed after 30 and after 90 days, neither in those sacrificed after 90 and after 180 days. Only comparing animals sacrificed after 30 and after 180 days a significant difference was detected which means that animals in Group I had a thicker pseudocapsule at the beginning of the experiment and the process of maturation and remodelation of collagen reduced the pseudocapsule thickness after 180 days of observation.

In Group II, the pseudocapsules were thinner from the beginning, meaning that the process of remodelation was more regular, which led to a significantly less thick pseudocapsule.

Although capsular contraction around the implants is a much discussed topic ${ }^{12,13}$ and various methods have been developed to prevent the contraction, the etiology of pseudocapsules remains unclear. The contraction could be caused by myofibroblasts, ${ }^{14}$ i.e., a specie of fibroblast that have a contraction property and that can be proven in an ultrastructural examination.

Further studies should be conducted to ascertain whether low intensity laser has the same effect when the implant surface is not smooth, to determine the impact of lasers with different wavelengths and to know if there are morphologic signals attesting to the efficiency of low intensity laser treatment from the ultrastructural viewpoint.

\section{Conclusion}

Low intensity laser influences the process of tissue reparation that takes place around the implants warrant by lowering the pressure on the implant as well as by reducing the thickness of pseudocapsules, suggesting this type of laser could be useful for modelation of contractions that appear around silicone implants.

\section{References}

1. Rees TD, LaTrenta GS. Breast augmentation. Aesthetic plastic surgery. 2ed. Philadelphia: Saunders; 1994. p.1003-49.

2. Rohrich RJ, Kenkel JM, Adams WP. Preventing capsular contracture in breast augmentation: in search of the Holy Grail. Plast Reconstr Surg. 1999;103(6): 1759-60.

3. Virden CP, Dobke MK, Stein P, Parsons CL, Frank DH. Subclinical infection of the silicone breast implant surface as a possible cause of capsular contracture. AesthPlast Surg. 1992;16(2):173-9.

4. Spear SL, Matsuba H, Romm S, Little JW. Methyl prednisolone in double-lumen gel-saline submuscular mammary prostheses: a double-blind, prospective, controlled clinical trial. Plast Reconstr Surg. 1991;87(3):483-7. 5. Silver H. Reduction of capsular contracture with two-stage augmentation mammoplasty and pulsed electromagnetic energy (Diapulse therapy). Plast Reconstr Surg. 1982;69(5):802-8.

6. Planas J, Migliano E, Wagenfuhr J, Castillo S. External ultrasonic treatment of capsular contractures in breast implants. Aesth Plast Surg. 1997;21(6):395-7.

7. Trelles MA, Mayayo E. Bone fracture consolidates faster with low-power laser. Lasers Surg Med. 1987;7(1):36-45.

8. Takeda Y. Irradiation effect of low-energy laser on alveolar bone after tooth extraction: experimental study in rats. Int J Oral Maxillofac Surg. 1988;17(6):388-91.

9. Gylbert LO. Applanation tonometry for the evaluation of breast compressibility. Scand J Plast Reconstr Surg Hand Surg. 1989;23(3):223-9. 10. Moore JR. Applanation tonometry of breasts. Plast Reconstr Surg. 1979;63:9-12.

11. Minami E, Koh IH, Ferreira JC, Waitzberg AF, Chifferi V, Rosewick TF, Pereira MD, Saldiva PH, de Figueiredo LF. The composition and behavior of capsules around smooth and textured breast implants in pigs. Plast Reconstr Surg. 2006;118(4):874-84.

12. Asplund O, Gylbert L, Jurell G, Ward C. Textured or smooth implants for submuscular breast augmentation: a controled study. Plast Reconstr Surg. 1996;97(6):1200-6.

13. Hakelius L, Ohlsen L. Tendency to capsular contracture around smooth and textured gel-filled silicone mammary implants: a five-year follow-up. Plast Reconstr Surg.1997;100(6):1566-9.

14. Camirand A, Doucet J. Breast augmentation: teaching our patients how compression can help prevent capsular contracture. Aesth Plast Surg. 2000;24(3):221-6

Conflict of interest: none

Financial source: none

\section{Correspondence:}

Aristides Palhares

Alameda Antonio Sartor, 430

18.607-340 Botucatu - SP Brazil

palhares@,fmb.unesp.br

Received: August 13, 2008

Review: October 15, 2008

Accepted: November 12, 2008

\section{How to cite this article}

Palhares A, Schellini SA, Pellizzon CH, Padovani CR, Dorsa P. Evaluation of low intensity laser's action on silicone mammary implant pseudocapsules in rats. Acta Cir Bras. [serial on the Internet] 2009 Jan-Feb;24(1). Available from URL: http://www.scielo.br/acb 